7. Hulych, O.I. (2014), Regulation of ecological safety in the region: European experience, Sotsiano-ekonomichni problemy suchasnoho periodu Ukrainy, Vol. 3, pp. 145-152 (ukr).

8. Didukh, V.R. (2008), Economic mechanisms for implementing the State Environmental Policy, Derzhavne budivnytstvo, Vol. 1, available at: http://nbuv.gov.ua/UJRN/DeBu_2008_1_15 (ukr).

9. Zarzhytskyy, O.S. (2012), Actual problems of legal support of ecological policy in Ukraine (theoretical aspects), Natsionalnyy hirnychyy universytet, Donetsk, 200 p. (ukr).

10. Ivanova, T.V. (2015), Ecological modernization of the regional economy, Naukovyy visnyk Akademii munitsypalnoho upravlinnya. Seriya "Upravlinnia», Vol. 3-4, pp. 229-237 (ukr).

11. Kovalenko, M.A. (2013), Economic mechanism for implementing ecological policy in Ukraine, Teoriya ta praktyka derzhavnoho upravlinnia i mistsevoho samovriaduvannia, Vol. 2, available at: http://nbuv.gov.ua/UJRN/Ttpdu_2013_2_5 (ukr).

12. Kravtsiv, V. (2007), Regional ecological policy in conditions of market economy in Ukraine (theory, methods, practice), Thesis for the degree of doctor of economic sciences after specialty 08.00 .06 "Environmental economics and environmental protection", Lviv, 373 p. (ukr).

13. Maziy, N.H. (2011), Principles and mechanisms of state regulation of business, Demokratychne vriaduvannia, Vol. 8, available at: http://nbuv.gov.ua/UJRN/DeVr_2011_8_8 (ukr).

14. Myronenko, M.Yu. (2012), The necessity of state regulation of economic development in modern conditions, Efektyvnist derzhavnoho upravlinnia, Vol. 32, pp. 433-440 (ukr).

15. Novikov, O.Ye. (2015), The specifics of state and market regulation of national economy in Ukraine, available at: https:// www.pdaa.edu.ua/sites/default/files/nppdaa/2011/02/178.pdf (ukr).

16. Pashkevych, M.S. (2012), Mechanisms of regulation ecological and economic regional development, Visnyk Berdianskoho universytetu menedzhmentu i biznesu, Vol. 3(19), pp. 143-147 (ukr).

17. Pishenina, T.I. (2011), Economic, essence role and importance of radiation in complex social development and national security syste, Visnyk Chernivetskoho torhovelno-ekonomichnoho instytutu. Ekonomichni nauky, Vol. (41), available at: http://chtei-knteu.cv.ual herald/content/download/archive/2011/v1/NV-2011-V1_18.pdf (ukr).

18. Khvesyk, M. and Bystriakov, I. (2012), Paradigmatic perspective on the concept of sustainable development of Ukraine, Ekonomika Ukrainy, Vol. 6, pp. 4-12 (ukr).

19. Chechel, A.O. (2013), Principles and mechanism of state regulation of the economy, Visnyk Akademii mytnoi sluzhby Ukrainy. Seriya Derzhavne upravlinnia, Vol. 2, pp. 103-111 (ukr).

20. Brownson, R.C., Baker, E.A., Housemann, R.A., Brennan, L.K., Bacak, S. J. (2001), Environmental and policy determinants of physical activity in the United States, American journal of public health, Vol. 91(12), pp. 1995-2003.

21. Lafferty, W. and Eivind, H. (2003), Environmental policy integration: towards an analytical framework, Environmental politics, Vol. 123, pp. 1-22.

(C) Білоскурський Руслан

Надійшла до редакції 04.12.2016

UDC 330.322

BRAILOVSKYI ILLIA,

Ph.D.

\title{
THE PUBLIC AND PRIVATE SECTORS OF THE ECONOMY: HISTORICAL ASPECTS OF COOPERATION
}

The article reviews the development of interaction between private capital and the state as a public-private partnership (PPP). The basic model of the original PPP, given their basic characteristics, considered the economic conditions of their origin and functioning.

Historically, the first form of public-private partnership made it possible to state to realize their economic, political and other interests. These relations continued to exist as long as the level of development of the state and its institutions are not given the opportunity to maximize the latter belonging to perform her functions. Protoforms PPP were not acts of the partnership (with the exception of certain elements of concession relations), and the delegation of certain functions of the state or the private sector elements. Therefore, most of the models of interaction between government and business have ceased to exist, and because so far the state is now true mainly for financial reasons, are not able to fully satisfy the public interest, to replace protoforms in the second half of the twentieth century. emerged and began to develop modern forms of publicprivate partnership.

Keywords: public-private partnership (PPP); history; protoform; occurrence; development.

Formulation of the problem. The interaction of the state and business in the framework of public-private partner- ship Public Private Partnership (PPP)since the late 90s of the twentieth centuryhas become one of the leading tools 
of effective implementation of socially important programs, especially in infrastructure sectors.

In modern scientific publications on the problems of PPP [1-6], historical aspects of interaction between the public and private sectors are generally considered or indirectly, or characterized by only some of its components. Such an approach not only allows you to trace the historical chain of PPP but also to determine what caused the need for such cooperation what were the motives of partnership that it forms were used and which ones can be used at this stage of economic development. In this regard, consideration of the genesis protoform PPP seems to us relevant.

Analysis of recent research and publications. Consider the most common approaches. Among Western scholars who in a given foot revealed the historical aspects of the topic of public-private partnerships can be called G. Agamben (особливості концесійних угод і їх розвиток у Європі) [4], G. Hodge [5] (изучение международного опыта ГЧП), M. Hellowell [9] (протоформи РPР у Великобританії)

Considered the most complete historical forms of PPP systematization and classification of historical forms of public-private partnerships, including experience in leases and concessions made in the Kapohuzova E. and Y. Solovyov [7], evolution and regulatory support public-private partnership is considered in the articleN. Kurys [8]. Analysis model of extra-budgetary control, which is used in Western countries since their formation to great administrative reforms of the nineteenth century contained in the Dutch researcher N. Caiden [10].

The purpose of this article is to examine the interaction of public and private sectors in historical protoform as public-private partnerships.

Presenting main material. Interaction between the public and private sectors in order to obtain certain benefits has a long history. Not very first form of this interaction was farmed out - the transfer of power to an individual for a certain period and under certain conditions the right to levy taxes and other fees and charges.

Within paying off the system state repayable transferred exclusive right to receive income from any activity, or use something private individual or private company.

The greatest significance of the ransom gained in the area of tax collection because of weak governance, fiscal underdevelopment, lack of accurate information about the state taxpayers and the importance of such activities to the state budget. One can say that the use of the state paying off the fiscal system in the industry was a necessary measure. Farmers on the basis of a documented agreement with the authorities brought to the treasury a (lump sum) amount or to collect taxes from the territory entrusted to him, compensate for it later, or after leaving a stipulated amount of collected [11, pp. 23-25].

Getting occurrence leases relates to VI cent. BC, yes, when Empire Ahemenydiv Persia (559-330 years BC) powers to collect tax on property in the satrapy (province) of Babylon were transferred to two banking families, who received compensation for their work. Leases can be found in the history of ancient Egypt (VI cent. BC). In the ancient Greece, in Athens, the developed system meets leases already in the VI cent. BC. In the Middle Ages ransom are common in France (from XIII cent.), in the Netherlands, Spain and England. Leases have become an important source of primitive accumulation of capital. With the development of capitalism ransom preserved in original form in Italy (XX cent.) As a collection of certain taxes by private banks, savings banks. In the USA in the late XIX early XX cent.existing forms of leases in collecting tax arrears. In Ukraine ransom were introduced in the late fifteenth - early sixteenth century. The main disadvantages of paying off the system were: opacity of operators, weaknesses opportunities to control and corrupt nature of the issue leases.

Note that the appearance of leases was due to the weakness of the then state institutions, underdeveloped financial system. Considering the economic components of the system of leases should note the following provisions. The public sector has certain requirements (in this case, finance, often - term) at the same time, it has the resources (facilities ransom: the right to collect taxes, the sale of alcoholic beverages, salt, etc.), development of which is possible, but only made for a long time, moreover, the absence or underdevelopment of state institutions (fiscal, economic, management) makes it impossible to efficiently realize the economic potential of these resources. The private sector has economic needs (for profit, the development of financial and social status), resource management positions that allow it to efficiently use resources. With the formation of economic relations within the leases, the parties enter into an agreement under which the state gives the private partner for a fixed term resources has, and return almost immediately receives a certain amount of funds, thus satisfying their direct interests. As optional, but may meet indirect economic needs of the state in favor of the possibility of a private partner loans received by those within the said interaction profit. The private partner invests in the facility's own resources (management) operates within a certain time for them to state resources, thus makes a profit, which covers investment. In addition to meet the direct needs - profit, private sector satisfy the consequential need of financial activities (including through the provision of debt loans state) and status needs (status of supplier / creditor imperial / royal court provides not only the political and social benefits, but also positively affects the economic activities of the private partner).

Another protoform of public-private partnerships in XIIIXIX cent. was privateering or piracy. One of the first attempts to regulate privateering made in 1288 the Aragonese king Alfonso III, who issued a decree under which the privateer had to obtain patents and make a pledge to ensure that they will not rob ship their citizens, not attacked by the enemy during the truce and in neutral ports. Legislation XIV-XV cent., for example, the law Genoa 1313-1316 y. Ordinance and the French King Charles VI in $1400 \mathrm{y}$. actually repeated the above provisions of the decree and added to them yet another demand - offering privateer oath that they will not do harm to their fellow citizens and their allies. Privateering lasted until the middle of the XIX century [6].

Very important role played privateering as sharingpublic and private initiatives, in fact - the predecessors of publicprivate partnership, the formation of the UK as a leading sea power. Privateering system has made a significant contribution to the protection of the British nation from foreign threats contributed to the development of maritime trade in the UK overall. Thanks to the "school privateering" was initiated by the so-called "race skippers, sailors and shipbuilding" which made possible the actual development of the Navy of Great Britain and establishing a worldwide empire. At the same time, it was also distorted (false) system, which weakened political influence. Thus, the negative of feature was the creation of models prevailing remuneration of officials not using public pay, but with fees and benefits that they can get from their activity - leading British officers positioned themselves patrons risky activities privateering, and even the Queen "joined priva- 
teering, lending their ships and money for the expedition, which was cause for robberies probably the most important " [12, p. 230]. According to British researcher Rudolf Klein (Rudolf Klein), mixing public and private interests has also been the root cause of the appearance of corruption in the British economic system [13].

Note that the use of privateering as protoform publicprivate partnership in the UK contained a certain paradox: promoting the development of a strong layer of traders, privateering became a social force that helped the British government policy to implement expansionist desire to create powerful maritime empire and stressed reciprocity many public and private interests, while it required the establishment of clear dividing line between public and private sectors to improve the efficiency of the state.

Like privateering, certain features of the partnership between the state and the private sector can be seen in the institute mercenary. By the XVIII century are not generally seen as a negative phenomenon, however, the emphasis on this begins to focus on the time when mature modern state begins to have a standing army, which is formed and provided by the state directly. The existence of mercenary institution at the time of formation of large national states in the XVII century has an economic aspect. Lacking sufficient funds for maintenance and support their armies, especially in a period of peace, states a substantial degree relied on private army for national defense purposes.

In the history of mankind have been cases of successful use of private armies. Mercenaries have existed in the world for millennia. The first evidence of this was found in Mesopotamia, in the 3rd millennium BC king of the Sumerian city of Ur resorted to the services of mercenaries.

Some nations and states generally specialize in supplying mercenaries. Thus, in the ancient world of Greek hoplites served throughout the Mediterranean. Greek heavy infantry fighting different skill parade (phalanx). Illustrative example: Alexander Macedonian, starting conquest of the Persian Empire (in his army were not only Macedonians, but also representatives of many Greek city) at the Battle of Granik was forced to destroy a phalanx of Greek mercenaries served local satraps. Alexander spared taken prisoner by the Persians, but ordered to kill all prisoners tribesmen [14, p. 117].

Institute mercenary in the Middle Ages existed in Ukraine. The most widespread mercenaries, in our view, include the Crimean Tatars. They seem to hire tens of thousands, sometimes dominating the number of troops by 100 thousand. People and serve it on the side against Ukrainian Poles, on the other side. Ukrainian Cossacks also fought throughout Europe. In August 1619 the Emperor Ferdinand II of Habsburg sends Rzeczpospolita their ambassadors to ask for help. But Sigismund III Vasa just completed an exhausting war with Moscow, as a maximum, which he could help the Allies Catholics - to send as condottiere (mercenary) Cossacks who were outside the registry (with 40,000 participants in the campaign it included only 6,000$)$. In October 1619 , at the height of the siege of Vienna Czechs and transylvantsyamy (Hungarians) to Transcarpathia invades 10,000th hull Cossacks led by Colonel Klichkovskym and Rusynovskym. November 22 Cossacks under Humenna transylvantsiv crushed under the command of Prince George Rakoczy. Shortly Cossacks besieged city of Kosice in Slovakia and Pryashov and their actions effectively thwarted plans Antyhabsburhskoyi coalition troops, forcing them to lift the siege on November 27 in Vienna.

One of the most ambitious projects of public-private partnerships in the XVII - the first half of the XIX cent.by the East India Company, which began to appear at the turn of
XVI-XVII centuries. In many ways, the East India Company lawfully called predecessors of modern multinationals: it is the first ever organization that bound all its activities known at the time of the world, and thanks to the centralized management system and distribution in some cases actually replaced national governments. Of course, the first revolutionary was the role of these companies in the organization and implementation of foreign trade. However, in the interests of research, and was significant role in the evolution of public (state) and private sectors. Starting as a small trading company, and then corporations, with little participation of the national state, then East India Company turned into a state within a state. We believe that the degree of autonomy, administrative, financial and other privileges of the East India company explains the degree of development of the national state. When the state raised the level of autonomy, the role of companies began to decrease and they stopped their activities (in fact - to address the same state). Elimination of the East India companies took place in France in the late XVIII century. British company lasted longer with greater economic weight, a huge territorial possession and that annexing Indian territory Britain would lead her to an armed conflict with other European countries that have interests in the East.

Another form of interaction between public and private sectors was the concession, which still remains one of the leading PPP. Concessions were in the XVII century in England, USA, France. The basis of the concession assignment of rights to certain economic activities or foreign non-domestic companies under certain conditions [2].

Concessions are not only economic but also political, when state territory in the established order interstate acts can be transferred to concession. The first concession for the development of mineral resources has been provided in Spain in 1256 year. The first concessions for oil for medical purposes was issued in Italy, near Mian where Medizano in 1400 year. In France the XVI century. State authorities tried to use private entrepreneurs to develop at their expense, but under control, economic activities that provide utility services for citizens or the economy as a whole. Thus, the first concession was granted in France where Adam craponne in 1554 to build the channel [4].

Concession agreements in their modern sense was first spread to continental Europe in the early XIX cent. and used first in France, then in Germany, Italy and other Western European countries, mainly in urban and municipal services, as well as for different objects monopoly of state property. Concession contract as a form of private investments into the national economy and is widely used by many countries that adapting such transactions to their specific needs and requirements of the national economy.

In the XVI-XVIII centuries. Concessions shaped special document issued by the State - authorization for possession of public property, which was unilateral act of its own state. In XIX cent. made concession agreement, a bilateral agreement. Of particular importance acquired concessions from the middle of the XIX cent. in the construction and reconstruction of transport infrastructure and exploitation of natural resources. They are widely used in France, Australia and Russia.

Thus, historically concessions emerged as a legalized form of contractual relations between the state (represented by government or municipal) and private investors in order to encourage the involvement and investment of capital in the development of the national economy. However, as a rule, such private investors attached to a string and oscillating on the right to use state and municipal 
property (including natural resources), and the right to exercise state monopoly activities.

Further development of public-private interaction gets in the 1960s of the XX cent. The USA projects under Urban Infrastructure with the participation of private investors (urban development projects). Modern forms and methods of public-private partnership there in the early 90 s XXcent., after this started active expansion philosophy and tools of PPP in new areas of economic activity (such as research and development, education, sports), and economical the practice of countries not previously covered by this process (Latin America, African countries, eastern Europe) [4].

Fig. 1 shows the dynamics of PPP protoform depending on the degree of state.
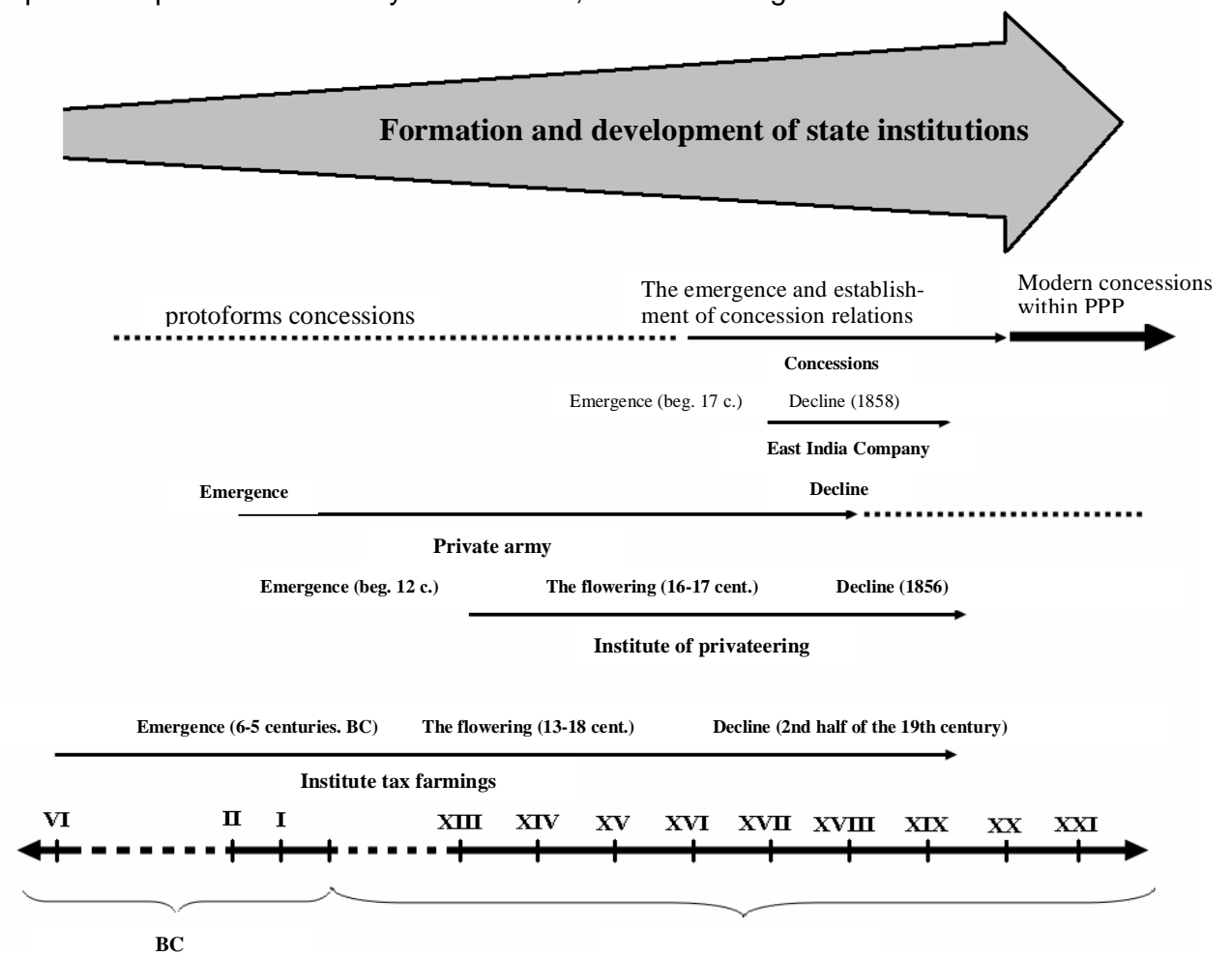

Fig.1 Historical development interactions public and private sectors (Authoring) [15, p. 47].

\section{CONCLUSIONS}

After analyzing the historical aspects of cooperation between the government and private sectors, it should be noted that almost all the models of such cooperation obeyed two main trends. The first - the interests of the parties, the second - lack of development of the state and its institutions.

The emergence of the phenomenon of leases, piracy, concessions and others. conditional on that country to exercise their functions required certain resources, primarily financial. Because of the undeveloped state institutions, it could not fully and currently necessary time, to realize their own economic, political and other interests. To solve the problems that this occurred, the state has delegated some of its functions and it has provided appropriate resources of the private sector, which on the one hand satisfy the financial needs of the state, often "prepaid" and on the other part went through the functions state and getting economic profit.

These relations continued to exist as long as the level of the state and its institutions are not allowed the latter to perform as fully affiliated functions. In our opinion, protoform PPP were not acts of partnership (with the exception of certain elements of concession relations) and delegation of certain state functions or elements of the private sector. Therefore, most of these models of interaction between the state and business ceased to exist, and because the state is still mostly for financial reasons, not in able to fully satisfy the public interest, to replace protoform in the second half of the XX cent. emerged and began to develop modern forms of public-private partnerships.

\section{REFERENCES}

1. Deryabina, M. (2008), Public-private partnerships: theory and practice, Voprosy Economiki (Moscow), № 8; 61-77 (rus).

2. Linev, I. (2011, January - March), From foreign experience the conclusion and implementation of concession agreements, Miestnoye samoupravleniye $v$ RossiyskoyFederatsii [Local SelfGovernment in the Russian Federation], p.45 (rus).

3. Talapina, E. (2009), Concession as a form of public-private partnership, Khoziaystvoipravo [Economy and the Law], № 4, p.72(rus).

4. Agamben, G. Foreign concessions: the past and future of a form of shared sovereignty, available at: http://risingpowers.open. ac.uk/documents/Publication/Extraterritoriality_print.pdf

5. Hodge, G. and Greve, C. (2005), The challenge of publicprivate partnerships: learning from international experience, Edward Elgar Publishing, Oxford, 368 p. DOI: 10.4337/ 9781845428082.

6. Wettenhall, R. Thinking seriously about public-private partnerships as an MDG tool, available at: //http://unpan1.un.org/ intradoc/groups/public/documents/eropa/unpan026304.pdf

7. Kapoguzov, E.A. and Solovyov, Y.V. (2011), Public-private partnership - the origins and evolution,Coll. works of Donetsk National Technical University. Ser. Economic, Vol. 40-1, pp. 106111 (rus).

8. Kurys, N.V. (2011), Public-private partnership as a historical and legal phenomenon, Society and Law, № 2, pp. 30-35 (rus).

9. Hellowell, Mark. (2010), The UK's Private Finance Initiative: history, evaluation, prospects. In: Hodge, Graeme, Greve, Carsten \& Boardman, Anthony. Eds. International Handbook on PublicPrivate Partnerships. Cheltenham: Edward Elgar and others. DOI: $10.4337 / 9781849804691.00023$. 
10. Caiden, N. (1980), Budgeting in Poor Countries: Ten Common Assumptions Re-Examined. Public Administration Review, Vol. 40, No. 1, pp. 40-46. DOI: 10.2307/976107

11. Telliford, George T. [editor] (2009), Public-private partnerships around the world, Nova Science Publishers, NY, 345 p. (eng).

12. Andrews, Kenneth R. (1964), Elizabethan Privateering: English Privateering During the Spanish War, 1585-1603, Cambridge University Press, Cambridge, $356 \mathrm{p}$
13. Klein, R. (2005), The public-private mix in the UK, in Maynard, A. (ed.), The Public Private Mix for Health, London, Nuffield Trust, 43-62 (eng).

14. Dupuy, T. (1970), The Encyclopedia of Military History, Janes Publishing Company, NY: Harper and Row, p.117 (eng).

15. Braylovskyy, I. A. (2014), Models and mechanisms of stateprivate partnership: implementation in Ukraine, East Publishing House, Donetsk, 375 p. (ukr).

Брайловський Ілля,

кандидат економічних наук

\section{ДЕРЖАВНИЙ І ПРИВАТНИЙ СЕКТОРИ ЕКОНОМІКИ: ІСТОРИЧНІ АСПЕКТИ СПІВПРАЦІ}

У статті проаналізовано історичні аспекти співробітництва державного і приватного секторів економіки. Зазначено, що практично всі моделі такого співробітництва підпорядковувалися двом головним тенденціям, перша - це інтереси сторін, друга - нерозвиненість держави та її інститутів.

Історично перші форми державно-приватного партнерства (ДПП) - відкупи, корсарство, концесії тощо давали можливість державі реалізувати свої економічні, політичні та інші інтереси. Подібні відносини, на думку автора, продовжували існувати доти, доки рівень розвитку держави та їі інститутів не дав змогу останній максимально повно виконувати приналежні їй функції. Автор доводить, що протоформи ДПП були не актами партнерства (за винятком окремих елементів концесійних відносин), а делегуванням окремих функцій держави або їх елементів приватному сектору. Тому більшість розглянутих моделей взаємодії держави й бізнесу припинили існувати, а оскільки й досі держава, щоправда зараз в основному з фінансових причин, не в змозі повною мірою задовольнити суспільні інтереси, на зміну протоформам у другій половині XX ст. виникли й почали розвиватися сучасні форми державно-приватного партнерства - "Build, Operate, Transfer" (BOT), "Build, Own, Operate, Transfer" (BOOT), "Build, Transfer, Operate" (BTO), "Build, Own, Operate" (BOO), "Build, Operate, Maintain, Transfer" (BOMT), "Design, Build, Own, Operate, Transfer" (DBOOT), "Design, Build, Finance, Operate" (DBFO).

Ключові слова: державно-приватне партнерство (ДПП); історія; протофрорми; виникнення; розвиток.

Брайловский Илья,

кандидат экономических наук

\section{ГОСУДАРСТВЕННЫЙ И ЧАСТНЫЙ СЕКТОРЫ ЭКОНОМИКИ: ИСТОРИЧЕСКИЕ АСПЕКТЫ СОТРУДНИЧЕСТВА}

В статье проанализированы исторические аспекты сотрудничества государственного и частного секторов экономики. Отмечено, что практически все модели такого сотрудничества подчинялись двум главным тенденциям, первая - это интересы сторон, вторая - неразвитость государства и его институтов.

Исторически первые формы государственно-частного партнерства (ГЧП) - откуп, корсарство (каперство), концессии и т.д. - давали возможность государству реализовать свои экономические, политические и другие интересы. Подобные отношения, по мнению автора, продолжали существовать до тех пор, пока уровень развития государства и его институтов не дал возможность последней максимально полно выполнять принадлежащие ей функции. Автор доказывает, что протоформы ГЧП были не актами партнерства (за исключением отдельных элементов концессионных отношений), а делегированием отдельных функций государства или их элементов частному сектору. Поэтому большинство рассмотренных моделей взаимодействия государства и бизнеса прекратили существовать, а поскольку до сих пор государство, правда сейчас в основном по финансовым причинам, не в состоянии в полной мере удовлетворить общественные интересы, на смену протоформ во второй половине XX в. возникли и начали развиваться современные формы государственночастного партнерства - "Build, Operate, Transfer" (ВOT), "Build, Own, Operate, Transfer" (BOOT), "Build, Transfer, Operate" (BTO), "Build, Own, Operate" (BOO), "Build, Operate, Maintain, Transfer" (BOMT), "Design, Build, Own, Operate, Transfer" (DBOOT), "Design, Build, Finance, Operate" (DBFO).

Ключевые слова: государственно-частное партнерство (ГЧП); история; протофрормы; возникновение; развитие.

(C) Брайловський Ілля

Надійшла до редакції 14.12.2016 